\title{
LEGITIMASI HASIL PEMILIHAN UMUM KEPALA DAERAH SERENTAK 2020 DI MASA PANDEMI COVID-19
}

\author{
Diastama Anggita Ramadhan; Fakultas Hukum Universitas Diponegoro, Jalan Prof. \\ Soedharto, S.H. Tembalang, Kota Semarang, Jawa Tengah; E-mail: Diastama.anggita@gmail.com
}

\begin{abstract}
Abstrak
Legitimasi merupakan salah satu komponen yang amat penting dalam setiap penyelenggaraan pemilihan umum. Menjadi permasalahan pada penelitian ini adalah pemilhan umum kepala daerah serentak tahun 2020 yang dilaksanakan ditengah-tengah kondisi Pandemi Covid-19. Perdebatan yang melingkupi pelaksanaan pemilihan umum kali ini adalah pelaksanaan pemilihan umum kepala daerah serentak yang dimungkinkan untuk mengancam keselamatan masyarakat. Artikel ini merupakan hasil penelitian dengan menggunakan metode penelitian yuridis normatif. Pendekatan pada penelitian ini adalah pendekatan perundang-undangan. Metode pengumpulan bahan hukum dilakukan dengan studi kepustakaan. Bahan hukum kemudian diolah dengan metode deduktif untuk menarik kesimpulan dari bahan-bahan hukum yang telah didapatkan. Hasil penelitian ini menyimpulkan bahwa legitimasi pemilihan kepala daerah serentak amat penting untuk memudahkan pemenang hasil pemilihan umum dalam menjalankan roda pemerintahan. Menurunnya partisipasi masyarakat dalam gelaran pemilihan umum akibat pandemi ini akan mempengaruhi legitimasi masyarakat terhadap roda pemerintahan kedepannya. Hal ini perlu diperhatikan agar pemerintah dapat menjalankan pemerintahannya dengan tetap mendapat dukungan masyarakat.
\end{abstract}

Kata Kunci: Pandemi Covid-19, Pemilihan Umum Serentak, Kepala Daerah, Legitimasi

\section{Abstract}

Legitimacy is a very important in any general election. The problem is the general election of regional leader in 2020 which was held in the midst of the Covid-19. The debate surrounding the general election this time is the general election for regional leader that can threaten the community. This research is being conducted using normative methods. The approach in this research is statue approach. The legal material is carried out by literature study method. The legal materials are then processed by deductive methods to extract the materials that have been obtained. This research conclude that the legitimacy regional election elections is very important for the winner of the general election in order to run the government. The decrease of public participation during this election was affected by the current pandemic situation. This needs to be considered since the leaders cannot run their governancy easily without any legitimacy.

Keywords: Covid-19 Pandemic, Outright Election, Regional Leader, Legitimacy

\section{PENDAHULUAN}

\section{Latar Belakang}

Sifat kedaerahan Indonesia yang amat kental membawa konsekuensi logis bahwa setiap daerah akan memiliki karakteristiknya masing-masing. Berdasarkan karakteristik tersebut, setiap pemangku kepentingan serta pejabat publik di tingkat daerah haruslah seseorang yang memang memiliki kompetensi serta kapabilitas dan pengetahuan kedaerahannya yang cukup tinggi. Hal ini menjadi penting mengingat pasca dibentuknya Undang-Undang yang secara spesifik mengatur mengenai Pemerintahan Daerah, Pemerintah Daerah memiliki kewenangan yang lebih mandiri untuk dapat melakukan manajemen pengelolaan daerahnya masing-masing. Guna tercapainya efisiensi dalam pelaksanaan pemilihan kepala daerah, proses pemilihan ini kemudian dilaksanakan 
secara serentak yang diperintahkan oleh Mahkamah Konstitusi melalui putusannya. ${ }^{1}$ Hal ini kemudian dikukuhkan melalui Undang-Undang Nomor 7 Tahun 2017 tentang Pemilihan Umum yang menyatakan pemilihan umum di Indonesia akan dilakukan secara serentak. ${ }^{2}$

Salah satu tujuan diadakannya pemilihan umum kepada daerah adalah guna terciptanya perbaikan situasi sosial, politik, dan perekonomian yang sesuai dengan karakteristik daerah. ${ }^{3}$ Mekanisme pemilihan kepala daerah secara langsung merupakan sarana bagi masyarakat daerah untuk memilih kepala daerah sesuai dengan kompetensi yang dimilikinya. Pemberlakuan mekanisme pemilihan kepala daerah secara langsung ini kemudian diharapkan dapat memudahkan rakyat untuk lebih menyuarakan aspirasinya secara langsung di daerah. Berdasarkan hal tersebut, pada dasarnya pemilihan kepala daerah adalah proses pemberian mandat melalui sebuah legitimasi dari masyarakat daerah kepada pasangan calon kepala daerah pemenang pemilu. ${ }^{4}$

Pelaksanaan pemilihan kepada daerah secara langsung ini kemudian memberikan 2 (dua) dampak positif bagi pelaksanaan demokrasi di tingkat lokal, yakni: ${ }^{5}$

1. Melalui pemilihan kepala daerah langsung, akan memberikan legitimasi bagi pemenang kontestasi pemilihan umum dari masyarakat di tingkat daerah

2. Legitimasi secara langsung ini kemudian membuat pemenang kontestasi pemilihan kepala daerah tidak memiliki keterikatan langsung dengan legislatif daerah, sehingga pertanggungjawaban dilakukan secara langsung kepada rakyat.

Menyoal mengenai legitimasi ini menjadi hal yang penting dalam proses pemilihan umum. Legitimasi merupakan salah satu unsur utama suksesnya pelaksanaan pemilihan umum. Hal ini terjadi karena legitimasi merupakan kunci utamanya diterimanya seorang pasangan calon pemenang kontestasi pilkada oleh masyarakat. Secara umum, legitimasi dapat diperoleh ketika pasangan calon pemenang pemilihan umum telah menyelesaikan seluruh rangkaian proses pemilihan umum kepala daerah hingga sampai ke tahapan gugatan sengketa hasil pemilu apabila memang ada. ${ }^{6}$

Tingkat partisipasi masyarakat kemudian dapat menjadi salah satu indikator kunci tingkat legitimasi pelaksanaan pemilihan umum kepala daerah. Menurut Marijan, meskipun keterlibatan masyarakat hanya sampai dengan tahapan pemilihan, namun hal tersebut telah menunjukkan bahwa pasangan calon pemenang kontestasi pemilu ini telah

\footnotetext{
${ }^{1}$ Lihat Pada Amar Putusan Mahkamah Konstitusi Nomor 14/PUU-XI/2013

2 Lihat pada Pasal 167 Undang-Undang Nomor 7 Tahun 2017 tentang Pemilihan Umum.

3 Singgih Choirul Rizki dan Yusuf Adam Hilman. (2020). "Menakar Perbedaan Opini Dalam Agenda Pelaksanaan Kontestasi Pilkada Serentak di Tengah Covid-19". Jurnal Muqqadimah: Jurnal Ilmu Sosial, Politik, dan Humaniora. Volume 4 Nomor 2 Agustus 2020. h. 145.

4 Cucu Sutrisno. (2017). "Partisipasi Warga Negara dalam Pilkada". Jurnal Pancasila dan Kewarganegaraan. Volume 2 Nomor 2, Juli 2017. h. 36.

5 Teten Jamaludin. (2019). "Pilkada Langsung: Kisah Sukses dan Problematika". Jurnal Politik Walisongo. Volume 1 Nomor 1 2019. h. 32.

6 Untung Sri Hardjanto. (2019). "Legitimasi Pemilihan Umum di Indonesia Tahun 2019". Administrative Law and Governance Journal. Volume 2 Nomor 1 2019. h. 110.
} 
mendapatkan legitimasi atau pengakuan dari masyarakat yang dalam hal ini adalah pemilih. ${ }^{7}$

Menjadi suatu permasalahan tersendiri, bahwa dunia internasional tengah menghadapi permasalahan bersama yang pada akhirnya mewajibkan seseorang untuk membatasi kegiatannya. Pandemi Covid-19 kemudian menjadi permasalahan bersama yang mengharuskan banyak negara di seluruh dunia untuk dapat mengurangi aktivitasnya. Akibatnya, banyak kegiatan-kegiatan baik yang berpengaruh secara langsung maupun tidak langsung terhadap tata kehidupan bernegara menjadi terpengaruh. Proses pemilihan umum menjadi salah satu kegiatan yang terdampak terjadinya pandemi ini. Menjadi salah satu perdebatan dalam proses pelaksanaan pemilihan umum ini adalah keselamatan masyarakat umum dihadapkan dengan hak konstitusional warga negara serta terancamnya proses demokrasi apabila pelaksanaan pemilihan kepala daerah mengalami penundaan. Indonesia sendiri pada akhirnya melaksanakan proses pemilihan kepala daerah serentak pada 9 Desember 2020 dengan diikuti oleh: 9 Provinsi, 224 Kabupaten, dan 37 Kota. ${ }^{8}$

Pro dan kontra menyelimuti pelaksanaan pilkada serentak di tengah kondisi pandemi Covid-19 ini. Beberapa alasan mendukung pelaksanaan pilkada serentak yakni: ${ }^{9}$ 1. Pelaksanaan amanat peraturan perundang-undangan yang tetap berjalan;

2. Melindungi hak konstitusional warga negara; dan

3. Mereduksi jumlah wilayah daerah yang hanya dipimpin oleh pejabat sementara yang memiliki kewenangan lebih terbatas.

Pemerintah berpendapat bahwa beberapa negara telah sukses melaksanakan proses kontestasi demokrasi ini yakni: Korea Selatan, Selandia Baru, dan Polandia. ${ }^{10}$ Hal ini kemudian menjadi berlawanan apabila disandingkan dengan asas Salus Populis Suprema Lex yang berarti adalah keselamatan rakyat adalah hukum paling tinggi. ${ }^{11}$ Pemerintah kemudian melakukan rotasi pelaksanaan pemilu kepala daerah serentak ini melalui PERPPU yang kemudian disahkan menjadi sebuah Undang-Undang. Undang-Undang ini melakukan pergeseran pelaksanaan pemilu kepala daerah serentak dari 23 Septermber 2020 menjadi 9 Desember 2020.12

7 Kacung Marijan. (2010). Sistem Politik Indonesia: Konsolidasi Demokrasi Pasca Orde Baru. Penerbit Kencana Media: Jakarta. h. 113.

8 Hakam. (2020). Dilema Pelaksanaan Pilkada Serentak di Tengah Ancaman Pandemi. https://ugm.ac.id/id/berita/20283-dilema-pelaksanaan-pilkada-serentak-di-tengah-ancamanpandemi. Diakses pada 21 Januari 2020.

9 Aprista Ristyawati. (2020). "Efektivitas Pelaksanaan Pilkada Serentak 2020 di Masa Pandemi Darurat Covid-19 di Indonesia". Jurnal Crepido. Volume 2 Nomor 2. November 2020. h. 4

${ }^{10}$ Tsarina Maharani. (2020). DPR: Beberapa Negara ada yang Sukses Laksanakan Pemilu di Tengah Pandemi. https://nasional.kompas.com/read/2020/09/22/12573411/dpr-beberapa-negara-adayang-sukses-laksanakan-pemilu-di-tengah-pandemi?page=all. Diakses pada 21 Januari 2021.

${ }^{11}$ Humas Mahkamah Konstitusi. (2020). Sekretaris Jendral Mahkamah Konstitusi: Keselamatan Warga Hukum Tertinggi. https://www.mkri.id/index.php?page=web.Berita\&id=16326. Diakses pada 21 Januari 2021.

${ }^{12}$ Lihat pada Pasal 201A ayat (2) pada Undang Undang Nomor 6 Tahun 2020 tentang Penetapan Peraturan Pemerintah Pengganti Undang-Undang Nomor 2 Tahun 2020 tentang Perubahan Ketiga atas Undang-Undang Nomor 1 Tahun 2015 tentang Penetapan Peraturan Pemerintah Pengganti 
Terkait dengan legitimasi, menjadi permasalahan disini adalah rendahnya tingkat partisipasi pemilihan kepala daerah yang dilaksanakan pada tahun 2020. Angka partisipasi pemilu kepala daerah berdasarkan rilis yang dikeluarkan oleh Komisi Pemilihan umum adalah sebagai berikut: ${ }^{13}$

Tabel 1. Tingkat Partisipasi Masyarakat pada Pemilu Kepala Daerah Serentak 2020

\begin{tabular}{|c|c|c|}
\hline $\begin{array}{c}\text { Pemilihan Umum Tingkat } \\
\text { Gubernur dan Wakil } \\
\text { Gubernur }\end{array}$ & $\begin{array}{c}\text { Pemilihan Umum Tingkat } \\
\text { Bupati dan Wakil Bupati }\end{array}$ & $\begin{array}{c}\text { Pemilihan Umum Tingkat } \\
\text { Walikota dan Wakil } \\
\text { Walikota }\end{array}$ \\
\hline $69,6 \%$ & $77.5 \%$ & $69.0 \%$ \\
\hline
\end{tabular}

Sumber: Komisi Pemilihan Umum Republik Indonesia

Hal ini menjadi permasalahan karena tingkat partisipasi yang hampir hanya mendekati $50 \%$ ini tentu akan mempengaruhi legitimasi hasil pemilihan umum kepala daerah serentak. Apabila dilakukan perbandingan dengan hasil pemilihan umum serentak yang dilaksanakan pada tahun 2015, total partisipasi masyarakat yang berpartisipasi dalam pemilihan umum ini mengalami penurunan sejumlah $10 \% .{ }^{14}$

Hal ini terjadi karena demokrasi langsung akan sangat terkait dengan legitimasi, maka tingkat partisipasi masyarakat ini akan sangat menentukan. Semakin rendahnya tingkat partisipasi masyarakat dalam proses kontestasi, maka legitimasi yang dihasilkan akan semakin rendah. ${ }^{15} \mathrm{Hal}$ ini kemudian menjadi sesuatu yang menarik untuk dikaji mengingat kondisi Pandemi Covid-19 akan mempengaruhi perhelatan kontenstasi pemilihan umum kepala daerah serentak pada tahun 2020. Berdasarkan latar belakang yang telah dijelaskan tersebut, maka penelitian ini diberi judul "LEGITIMASI HASIL PEMILIHAN UMUM KEPALA DAERAH SERENTAK 2020 DI MASA PANDEMI COVID-19"

\section{Rumusan Masalah}

Berdasarkan pendahuluan yang telah diajukan, maka dalam penelitian kali ini akan diangkat beberapa perumusan masalah yang akan menjadi pokok bahasan pada artikel ini. Perumusan masalah dalam artikel ini antara lain:

1. Teori-teori apa sajakah yang dipergunakan untuk menguatkan argumen legitimasi?

Undang-Undang Nomor 1 Tahun 2014 tentang Pemilihan Gubernur, Bupati, dan Walikota Menjadi Undang-Undang

13 Sania Mashabi. (2020). KPU: Partisipasi Pemilih di Pilkada 2020 Capai 76.09 Persen. https://nasional.kompas.com/read/2020/12/31/18260221/kpu-partisipasi-pemilih-di-pilkada2020-capai-7609-persen?page=all. Diakses pada 21 Januari 2021.

14 Elina Budiarti. (2015). Di Balik Partisipasi Pilkada 2015 yang Menurun. https://www.bbc.com/indonesia/berita_indonesia/2015/12/151210_indonesia_pilkada. Diakses pada 29 Januari 2021.

${ }^{15}$ Andi Chandra, Erik Darmawan, dan Yesi. (2018). “Upaya Komisi Pemilihan Umum Provinsi Sumatera Selatan dalam Meningkatkan Partisipasi Pemilih pada Pilkada Serentak 2018 dan Pemilu Serentak 2019". Jurnal Studi Sosial dan Politik. Volume 2 Nomor 1. Juni 2018. h. 14. 
2. Bagaimanakah pelaksanaan pemilihan umum dalam kondisi darurat Pandemi Covid19 ?

3. Bagaimanakah legitimasi pelaksanaan pemilihan kepaa daerah serentak tahun 2020 ?

\section{METODE PENELITIAN}

Penelitian ini merupakan penelitian dengan jenis penelitian yuridis normatif. Pendekatan yang digunakan dalam penulisan ini merupakan pendekatan perundangundangan (statue approach). Metode yang digunakan guna mengumpulkan bahan hukum dalam penelitian ini mempergunakan metode studi literatur. Penelitian ini menggunakan metode analisa bahan hukum deduktif dimana bahan-bahan hukum yang telah dikumpulkan kemudian diklasifikasikan untuk kemudian menyimpulkan bahan hukum yang sifatnya umum menjadi hal yang lebih spesifik.

\section{PEMBAHASAN}

\section{A. Teori-Teori Legitimasi}

Legitimasi menjadi hal yang sangat penting dalam sebuah proses demokrasi. Menurut Lindblom legitimasi merupakan suatu kondisi dimana sistem suatu organisasi dengan sistem kemasyarakatan berjalan secara kongruen yang mana keduanya merupaka satu kesatuan yang utuh. Ketika terjadi kesenjangan antara kedua elemen tersebut, maka dimungkinan terjadinya kekacauan. ${ }^{16}$ Terkait dengan pelaksanaan proses demokrasi kemudian, hal ini menyebabkan legitimasi menjadi sesuatu yang mendesak mengingat peserta pemilihan umum dapat dikatakan sebagai pemenang ketika mendapatkan legitimasi dari masyarakat melalui proses tersebut. Menurut Kevin Clements, legitimasi didefinisikan sebagai berikut: ${ }^{17}$

"Legitimacy can be catagorized as the relation or social contract between the government and the people. This specific relation or contract will guarantee any rights and welfare of the community. when welfare is not reached, it means that legitimacy has been misused."

Melalui penerapan sistem representasi, legitimasi menjadi sangat penting utamanya pada setiap kondisi pengambilan kebijakan. Kebijakan yang diambil oleh subjek hukum yang terpilih dan mendapatkan legitimasi melalui pemilihan umum akan sangat berdampak terhadap pemilih yang dalam hal ini adalah masyarakat. Menjadi pemenang kontes demokrasi tanpa diikuti dengan legitimasi dari masyarakat akan sangat membahayakan kondisi demokrasi itu sendiri. Hal tersebut memungkinkan timbulnya penyalahgunaan pengaruh, sifat manipulatif terhadap kebijakan yang dihasilkan, serta timbulnya perlakuan koersi. ${ }^{18}$ Indikasi lemahnya

\footnotetext{
16 Yoremia Lestari Ginting. (2016). "Mekanisme Tata Kelola dan Pengungkapan Tanggung Jawab Sosial Perusahaan". Kinerja: Jurnal Ekonomi dan Manajemen. Volume 13 Nomor 1. h. 75.

17 Kevin P. Clements. (2014). What is Legitimacy and Why Does It Matter for Peace? https://rcservices-assets.s3.eu-west-1.amazonaws.com/s3fs-public/Accord25_WhatIsLegitimacy_0.pdf. Diakses pada 30 Januari 2021.

18 Alfan Alfian. (2009). Menjadi Pemimpin Politik: Perbincangan Kepemimpinan dan Kekuasaan. Gramedia Pustaka Utama: Jakarta, h. 233.
} 
legitimasi pada dasarnya amat dekat dengan kehidupan masyarakat Indonesia. Gejalagejala paling umum yang terjadi di berbagai belahan dunia terhadap absennya legitimasi hasil pemilihan umum antara lain adanya tindakan kekerasan masyarakat, demonstrasi, protes, krisis terhadap sistem pemerintahan, dan yang paling membahayakan adalah hilangnya kepercayaan masyarakat terhadap proses pemilihan umum. ${ }^{19}$

Easton berpendapat bahwa dalam sebuah sistem ketatanegaraan, terdapat 3 (tiga) objek yang memerlukan legitimasi secara langsung dari masyarakat yakni: pemerintahan, rezim, dan ekosistem politik. ${ }^{20}$ Melalui sistem pemilihan umum, legitimasi yang didapatkan akan memudahkan berjalannya ketiga hal tersebut sehingga hubungan antara masyarakat dengan pemenang kontestasi pemilihan umum akan berjalan dengan baik. Secara umum, menurut Eman Hermawan, terdapat 3 (tiga) metode untuk memperoleh legitimasi, yakni antara lain:21

1. Legitimasi Simbolis yang berarti bahwa legitimasi didapatkan dari simbol-simbil yang hidup dalam masyarakat. Simbol-simbol teresebut antara lain: budaya, agama, kepercayaan, moral, dan tradisi masyarakat. Pada legitimasi simbolis ini cenderung tidak memiliki sistem yang baku.

2. Legitimasi Material yang cenderung kepada tata cara memperoleh legitimasi dengan cara menjanjikan untuk memberikan sesuatu, menjanjikan sesuatu kepada para pemberi legitimasi (dalam hal ini masyarakat luas).

3. Legitimasi Prosedural yang berarti bahwa legitimasi dijalankan dengan melalui prosedur-prosedur tertentu yang telah diatur oleh negara. Kedua belah pihak baik negara maupun masyarakat haruslah mengakui adanya prosedur yang telah dibuat ini sehingga nanti proses pemberian legitimasi akan berjalan dengan baik dan pemerintahan yang dihasilkan akan kuat.

Sebagai negara yang menganut sistem demokrasi, Indonesia cenderung mengarah kepada legitimasi prosedural sebagai sarana untuk memperoleh pengakuan dari masyarakat. Menurut Kimmo dan Maija, dalam pelaksanaan demokrasi prosedural melalui sistem pemilihan umum ini, harus ada rasa percaya masyarakat kepada lembaga yang ditunjuk untuk melaksanakan sistem pemilihan umum tersebut. Maka menurut Kimmo dan Maija, legitimasi tidak hanya mengenai penyerahan kewenangan dari masyarakat kepada pemenang pemilu, namun juga memberikan kepercayaan masyarakat untuk dapat dikelola dalam suatu sistem pemerintahan.22 Berdasarkan hal tersebut, teramat penting bagi sebuah mekanisme dan prosedur demokrasi untuk selalu mendapatkan legitimasi yang utuh dari

19 Martin Moore dan Damian Tambini. (2018). Digital Dominance, The Power Of: Google, Amazon, Facebook, and Apple. Oxford University Press: Oxford. h. 268.

${ }^{20}$ Ramlan Surbakti. (2009). Memahami Ilmu Politik. Grasindo: Jakarta. h. 93.

${ }^{21}$ Eman Hermawan. (2005). Politik Memberla yang Benar. DKN Garda Bangsa: Yogyakarta. h. 5.

${ }^{22}$ Kimmo Gronlund dan Maija Setala. (2004). Low Electoral Turnout an Indication of Legitimacy Defisit? https://ecpr.eu/Filestore/paperproposal/d83ddd59-0a00-4535-a117-55a859e6a630.pdf. Diakses pada 30 Januari 2021. 
seluruh komponen negara. Pengakuan terhadap keutugan legitimasi ini akan membuat proses bernegara menjadi semakin baik.

\section{B. Pelaksanaan Pemilihan Umum pada Kondisi Darurat Covid-19}

Era pemilihan umum serentak sendiri mulai bergulir pasca Putusan Mahkamah Konstitusi yang mengamanahkan pelaksanaan pemilihan umum untuk dilakukan secara bersamaan pada setiap tahapannya. Hal ini kemudian termasuk dengan pelaksanaan pemilihan umum kepala daerah. Beberapa alasan mengapa pemilihan umum dilaksanan secara serentak antara lain:23

1. Hak seorang warga negara untuk dapat memilih secara cerdas pada kontestasi pemilihan umum sehingga seorang warga negara dapat menentukan sendiri peta jalan checks and balances yang dibangun melalui konsep pemilihan umum;

2. Hak seorang warga negara untuk dapat memilih secara efektif dan efisien. Efisien dapat diartikan efisien waktu, efisien biaya, serta efisien tenaga secara lebih terjamin dalam hukum;

3. Hak seorang warga negara untuk memperoleh pelayanan yang lebih baik dari negara melalui penghematan biaya pelaksanaan pemilihan umum;

4. Sebagai sarana pendidikan berpolitik bagi partai politik agar lebih cermat melakukan proses kaderisasi anggota partai politk; dan

5. Guna mereduksi dan perlahan diharapkan dapat menghilangkan proses korupsi, politik uang, dan segala tindakan tidak terpuji lainnya yang kerap kali terjadi pada proses pelaksanaan pemilihan umum.

Pelaksanaan pemilihan kepala daerah secara serentak pun menjadi sangat mendesak untuk dilaksanakan sebagai salah satu sarana mempercepat proses pembangunan bangsa. Konstruksi ketatanegaraan dalam proses pemilihan kepala daerah secara serentak ini adalah guna tercapainya dukungan secara maksimal terhadap sistem presidensiil di Indonesia sehingga pemerintah di tingkat lokal tidak lagi disibukkan dengan proses pemilihan dilaksanakan secara tidak bersamaan. Ketidakpaduan pelaksanaan pemilihan kepala daerah ini menyebabkan jalannya roda pemerintahan di tingkat lokal menjadi tidak maksimal dan tidak efisien. ${ }^{24}$ Indonesia sendiri mulai mempraktikkan pelaksanaan pemilihan kepala daerah secara serentak pada tahun 2015.

Menjadi permasalahan adalah manakala tejadi kondisi-kondisi yang berada diluar kendali dan perncanaan pemerintah, maka praktik ketatanegaraan pun dipaksa untuk mengikuti dinamika tersebut. Kondisi darurat seperti Pandemi Covid-19 yang terjadi pada periode tahun 2020 ini memaksa banyak negara untuk melakukan penyesuaianpenyesuaian terhadap praktik ketatanegaraan, termasuk Indonesia. Secara internasional pada dasarnya telah diatur dalam sebuah perjanjian internasional yang telah diratifikasi oleh pemerintah Republik Indonesia. Bahwa negara dapat melakukan

${ }^{23}$ Ria Casmi Arrsa. (2014). "Pemilu Serentak dan Masa Depan Konsolidasi Demokrasi". Jurnal Konstitusi. Volume 11 Nomor 3. September 2014. h. 522-523.

24 Achmad Arifulloh. (2015). "Pelaksanaan Pilkada Serentak yang Demokratis, Damai, dan Bermartabat". Jurnal Pembaharuan Hukum. Volume 2 Nomor 2. Agustus 2015. h. 301. 
penundaan terhadap diberikannya hak-hak masyarakat selama terdapat kondisi spesifik tertentu yang menyebabkan pemberian dan/atau pelaksanaan hak-hak sipil masyarakat harus ditunda. ${ }^{25}$ Menurut Smith, akan lebih konstitusional secara praktik bahwa pelaksanaan pemilihan umum dilakukan lebih cepat daripada ditunda atau bahkan ditiadakan. ${ }^{26}$ Beberapa alasan kedaruratan yang dapat menjadi alasan bahwa pemilu akan ditunda atau tatap dijalankan dalam kondisi tertentu antara lain:27

Tabel 2. Kualifikasi Keadaan Darurat

\begin{tabular}{|r|l|l|}
\hline No & \multicolumn{1}{|c|}{$\begin{array}{c}\text { Jenis Keadaan } \\
\text { Darurat }\end{array}$} & \multicolumn{1}{|c|}{ Bentuk Keadaan Darurat } \\
\hline 1. & $\begin{array}{l}\text { Keadaan Darurat } \\
\text { yang disebabkan } \\
\text { oleh Alam }\end{array}$ & $\begin{array}{l}\text { a. } \text { Geospasial : Gempabumi, tanah longsor, tsunami, } \\
\text { aktivitas gunung berapi; } \\
\text { b. Hidrologikal : Banjir, Tanah Longsor, Ombak } \\
\text { Tinggi; } \\
\text { c. Klimatologikal : Kekeringan, Kebakaran Hutan; } \\
\text { d. Biologikal : Epidemi, Pandemi; } \\
\text { e. Sebab lain : Kejadian luar angkasa, meteorit }\end{array}$ \\
\hline 2. & $\begin{array}{l}\text { Keadaan Darurat } \\
\text { yang disebabkan } \\
\text { oleh manusia }\end{array}$ & $\begin{array}{l}\text { Konflik, pengungsi terlantar, kecelakaan industrial, } \\
\text { kecelakaan transportasi, kegagalan teknologi, } \\
\text { kecelakaan yang diakibatkan hal lain (terorisme) }\end{array}$ \\
\hline
\end{tabular}

Sumber: Center for Research on Epidemology of Disaster (CRED)

Berangkat dari kategori tersebut, pandemi covid-19 dapat dikategorikan sebagai salah satu alasan guna menunda pelaksanaan pemilihan kepala daerah serentak pada tahun 2020. Munculnya desakan guna melakukan penundaan didasarkan pada beberapa alasan antara lain: meningkatnya postivity rate pengidap virus covid-19, terjadinya korupsi serta politisir pemberian bantuan sosial, ketidakseimbangan kontestasi pemilihan umum antara petahana dan nonpetahana, dan menurunya tingkat partisipasi masyarakat sebagai pemenuhan legitimasi. ${ }^{28}$

${ }^{25}$ Lihat pada Pasal 4 International Covenant of Civil and Political Rights sebagaimana diratifikasi melalui Undang-Undang Nomor 12 Tahun 2005 tentang Pengesahan International Covenant of Civil and Political Rights.

${ }^{26}$ Alsatair Smith. (2004). Election Timing. Cambridge University Press: Cambridge. h. 72.

${ }^{27}$ Regina Below, Angelika Wirts, dan Debarati Guha. (2009). Disaster Category Classification and Peril Terminology for Operational Purposes. Center for Research on Epidemology of Disaster: Munich. h. 58.

28 Abdul Rochim. (2020). Penundaan Pilkada, Rem Darurat Cegah Klaster Baru Covid-19. https://nasional.sindonews.com/read/162040/12/penundaan-pilkada-rem-darurat-cegahkluster-baru-covid-19-1599869369?showpage=all. Diakses pada 2 Februari 2021. 
Melakukan penundaan terhadap proses pemilihan umum bukanlah hal yang baru dalam dunia demokrasi modern. Tercatat setidaknya terdapat 7 (tujuh) tipologi penundaan pemilihan umum yang telah dikenal, antara lain:29

Tabel 3. Tipologi Penundaan Pelaksanaan Pemilihan Umum

\begin{tabular}{|c|l|c|c|}
\hline No & Kendala yang Menghentikan & $\begin{array}{c}\text { Siapa yang Melakukan } \\
\text { Penundaan }\end{array}$ & $\begin{array}{c}\text { Kapan } \\
\text { Dilakukan } \\
\text { Penundaan }\end{array}$ \\
\hline 1. & Pembatalan Total & Petahana; Militer & $\begin{array}{c}\text { Pra-pemilihan } \\
\text { umum }\end{array}$ \\
\hline 2. & Penundaan karena terjadi krisis & Petahana; Oposisi & $\begin{array}{c}\text { Pra-pemilihan } \\
\text { umum }\end{array}$ \\
\hline 3. & $\begin{array}{l}\text { Penundaan karena terjadi } \\
\text { transisi pemerintahan }\end{array}$ & $\begin{array}{c}\text { Proses Transisi } \\
\text { Pemerintahan }\end{array}$ & $\begin{array}{c}\text { Pra-pemilihan } \\
\text { umum }\end{array}$ \\
\hline 4. & Penundaan karena alasan teknis & $\begin{array}{c}\text { Petahana; Institusi } \\
\text { Penyelenggara } \\
\text { Pemilihan Umum }\end{array}$ & $\begin{array}{c}\text { Pra-pemilihan } \\
\text { umum }\end{array}$ \\
\hline 5. & $\begin{array}{l}\text { Penundaan karena } \\
\text { meninggalnya kandidat kuat } \\
\text { peserta pemilihan umum }\end{array}$ & $\begin{array}{c}\text { Petahana; Institusi } \\
\text { Penyelenggara } \\
\text { Pemilihan Umum }\end{array}$ & $\begin{array}{c}\text { Pra-pemilihan } \\
\text { umum }\end{array}$ \\
\hline 6. & $\begin{array}{l}\text { Penundaan karena alasan } \\
\text { kemanusiaan }\end{array}$ & $\begin{array}{c}\text { Petahana; Institusi } \\
\text { Penyelenggara } \\
\text { Pemilihan Umum }\end{array}$ & $\begin{array}{c}\text { Pra-pemilihan } \\
\text { umum }\end{array}$ \\
\hline 7. & $\begin{array}{l}\text { Tidak diakuinya pemilihan } \\
\text { umum }\end{array}$ & $\begin{array}{c}\text { Putusan Pengadilan; } \\
\text { Petahana; Militer }\end{array}$ & $\begin{array}{c}\text { Pasca pemilihan } \\
\text { umum }\end{array}$ \\
\hline
\end{tabular}

Sumber: Election Law Journal

Pelaksanaan pemilihan kepala daerah serentak pada tahun 2020 ini pada dasarnya memiliki kesempatan untuk dilakukan penundaan dengan alasan kemanusiaan. Beberapa negara pernah melakukan penundaan pelaksanaan pemilihan umum baik di tingkat lokal maupun nasional karena alasan darurat. Beberapa negara tersebut antara lain: ${ }^{30}$

Tabel 4. Negara-Negara yang Melakukan Penundaan Pemilihan Umum karena Kondisi Kedaruratan

\begin{tabular}{|c|c|c|c|}
\hline No & $\begin{array}{c}\text { Negara yang Menunda } \\
\text { Pemilu }\end{array}$ & $\begin{array}{c}\text { Waktu } \\
\text { Penundaan } \\
\text { Pemilu }\end{array}$ & Alasan Penundaan \\
\hline 1. & Namibia & $2013-2016$ & Wabah Penyakit Ebola \\
\hline 2. & Gambia & $2013-2016$ & Wabah Penyakit Ebola \\
\hline 3. & Republik Kongo & $2013-2016$ & Wabah Penyakit Ebola \\
\hline
\end{tabular}

29 Toby James dan Sead Alihodzic. (2020). “When Is It Democratic To Postpone an Election? Elections During Natural Disasters, Covid-19, and Emergency Situation". Election Law Journal. Volume 19 Nomor 3. h. 347.

30 Charlotte Cousins. (2020). Holding Elections During the Covid-19 Pandemic. https://data.oireachtas.ie/ie/oireachtas/libraryResearch/2020/2020-12-16_l-rs-note-holdingelections-during-the-covid-19-pandemic_en.pdf. Diakses pada 3 Februari 2021. h. 2. 


\begin{tabular}{|c|c|c|c|}
\hline 4. & Republik Liberia & $2013-2016$ & Wabah Penyakit Ebola \\
\hline 5. & Meksiko & 2009 & Wabah Penyakit Flu Burung \\
\hline
\end{tabular}

Sumber: House of the Oireachtas Research Service

Indonesia sendiri telah memiliki instrumen hukum yang memungkinkan untuk melakukan penundaan pelasanaan pemilihan umum manakala terjadi situasi kerusuhan, gangguan keamanan, bencana alam, atau gangguan lainnya di sebagian atau seluruh wilayah pemilihan di Indonesia. ${ }^{31}$ Pemerintah Republik Indonesia kemudian telah melakukan waktu pergeseran pelaksanaan pemilihan kepala daerah serentak 2020 melalui sebuah peraturan perundang-undangan. Beberapa alasan bahwa pemilihan kepala daeran serentak tidak bisa ditunda untuk yang kedua antara lain:32

1. Jumlah daerah yang telah habis masa jabatannya cukup banyak sehingga kepala daerah yang telah habis masa jabatannya akan digantikan dengan seorang pelaksana tugas (PLT) yang tidak memiliki kewenangan penuh layaknya kepala daerah definitif.

2. Masih belum dapat diperkirakan waktu yang pasti mengenai berakhirnya Pandemi Covid-19. Melakukan penundaan dan menunggu status pandemi dicabut tidak memberikan kepastian pelaksanaan pemilihan kepala daerah serentak dari segi waktu.

3. Tidak maksimalnya pelaksanaan pelayanan masyarakat akibat pelaksanaan roda pemerintahan yang tidak optimal.

Berdasarkan pada alasan-alasan tersebut, pemerintah Republik Indonesia tetap melaksanakan pemilihan kepala daerah secara serentak pada tanggal 9 Desember 2020 dengan menggunakan landasan hukum PERPPU. Legitimasi hasil pemilihan kepala daerah serentak ini kemudian merupakan sesuatu yang harus dijaha mengingat legitimasi menjadi dasar kuat pengakuan masyarakat terhadap pemenang kontestasi pemilihan umum.

Meskipun banyak negara yang pada akhirnya turut serta melakukan penundaan kontestasi demokrasi baik di tingkat lokal maupun nasional, namun tidak sedikit pula negara yang akhirnya tetap bertahan untuk melaksanakan proses pemilihan umum. Hal yang sangat dipertimbangkan dalam pemaksaan pelaksanaan pemilihan umum ditengah kondisi Pandemi Covid-19 antara lain adalah integritas elektoral. Integritas elektoral dapat didefinisikan sebagai: ${ }^{33}$

${ }^{31}$ Lihat pada Pasal 120 Undang-Undang Nomor 1 Tahun 2015 tentang Penetapan Peraturan Pemerintah Pengganti Undang-Undang Nomor 1 Tahun 2014 tentang Pemilhan Gubernur, Bupati, dan Walikota menjadi Undang-Undang.

32 Yoga Pongluturan, Martha Eliza Sellyn, Adryan Frediyanto. (2020). Kacamata Driyarkara : Pelaksanaan Pilkada 2020 di Titik Nadir. https://usd.ac.id/mahasiswa/bem/f1l3/Kajian\%20Pilkada\%20Pandemi\%20SPKS.pdf. Diakses pada 3 Februari 2021.

33 Pippa Noris, Richard Frank, dan Ferran Martinez. (2014). Measuring Electoral Integrity Around the World: A New Dataset. https://core.ac.uk/download/pdf/71804807.pdf. Diakses pada 3 Februari 2021. h. 788. 
"Pelaksanaan pemilihan umum yang menjunjung tinggi prinsip dan asas demokrasi, menghormati hak-hak setiap pemilih, sesuai dengan prinsip-prinsip internasional, dilaksanakan secara profesional, imparsial, dan transparan baik dalam tahapan persiapan maupun pelaksanaan dalam sebuah siklus pemilihan umum."

Integritas elektoral inilah yang kemudian harus dijadikan dasar pada setiap proses pemilihan umum. Menurut James dan Alidhozic, pemilihan umum yang dilaksanakan ketika Pandemi Covid-19 berlangsung haruslah memenuhi beberapa kriteria berikut: ${ }^{34}$

1. Menjadikan ancaman bagi para pemilih untuk melakukan pertimbangan terhadap kandidat mana yang akan dipilih, apabila pemilihan umum harus ditunda;

2. Mewujudkan keseimbangan dalam kontestasi pemilihan umum. Hal ini penting mengingat dalam kondisi darurat, pasangan calon petahana akan sangat mendapatkan keuntungan karena petahan akan lebih terlihat oleh calon pemilih dalam proses penanganan kondisi darurat tersebut.

3. Kepastian dalam Pemerintahan. Meskipun pelaksanaan pemilihan umum diwaktu pandemi memiliki banyak tantangan, namun dengan tetap melaksanakannya akan memberikan kepastian bagi berjalannya roda pemerintahan dimasa yang akan datang.

4. Pemerintah melalui penyelenggara pemilihan umum harus bisa menjamin keselamatan baik panitia penyelenggara maupun pemilih dengan menyediakan segala kebutuhan pengaman kesehatan (personal protective equipment).

Beberapa negara yang melaksanakan pemilihan umum di tingkat nasional maupun lokal antara lain:

a. Korea Selatan

Negara Korea Selatan melaksanakan proses pemilihan umum pada April 2020. Otoritas Pelaksana Pemilu di Korea Selatan, National Election Commission menyiapkan beberapa metode pemilihan umum guna meminimalisir resiko terjadinya penularan. Salah satu contoh yang berhasil dilaksanakan di Korea Selatan adalah layanan jemput bola kepada pemilih yang sedang dalam masa karantina maupun kepada masyarakat yang sedang mengalami pembatasan wilayah. ${ }^{35}$ Pada pemilihan langsung di Korea Selatan menggunakan protokol kesehatan ketat. 36

\section{b. Selandia Baru}

Negara Selandia Baru telah menggeser waktu pelaksanaan pemilihan umum dari yang semula 19 September 2020 menjadi 17 Oktober 2020. Otoritas pemilihan

\footnotetext{
${ }^{34}$ Toby James dan Sead Alihodzic. Loc. Cit. h. 345.

${ }^{35}$ Antonio Spinelli. (2020). Managing Election Under the Covid-19 Pandemic: The Republic of Korea's Crucial Test. International IDEA Technical Paper. idea.int/sites/default/files/publications/managing-elections-during-pandemic-republic-koreacrucial-test.pdf. diakses pada 3 Februari 2021, h. 3.

36 Republic of Korea National Election Commission. (2020). Election Management in Response to Covid-19. Republic Of Korea National Election Commission, h. 5.
} 
umum di Selandia Baru, menjalankan beberapa langkah disamping protokol kesehatan yang amat ketat. Langkah-langkah tersebut adalah menambah lokasi pemungutan suara bagi para pemilih, pemilih diminta untuk memilih di daerah tempat tinggalnya, melakukan pemilihan jemput bola bagi para pemilih yang sedang dalam masa karantina maupun terkena pembatasan wilayah. ${ }^{37}$

c. Polandia

Sebagai negara yang umur demokrasinya belum panjang, Polandia memilih untuk tetap melaksanakan kontestasi pemilihan umum Presiden ditengah kondisi Pandemi Covid-19. Tahapan yang ditempuh Polandia untuk melaksanakan proses pemilihan umum ditengah Pandemi adalah dengan mengubah metode pemilihan menjadi postal voting atau pemilih mengirimkan pilihannya melalui surat yang telah disediakan oleh otoritas penyelenggara pemilihan umum di Polandia. Surat pilihan tersebut akan dikirimkan secara langsung kepada Otoritas Penyelenggara Pemilu di Polandia. ${ }^{38}$

Negara-negara tersebut memilih untuk tetap melaksanakan pemilihan umum dengan tetap mengedepankan keselamatan masyarakat sebagai hukum tertinggi.

\section{Legitimasi Hasil Pemilihan Umum Kepala Daerah Tahun 2020}

Pemilihan umum kepala daerah di Indonesia yang dilaksanakan secara serentak pada tahun 2020 ini membawa sederet permasalahan, utamanya terkait dengan tataran pelaksanaan. Kondisi pertentangan antara pemenuhan hak konstitusional dan keselamatan warga negara sebagai sebuah hukum tertinggi menjadi perdebatan yang melingkupi pelaksanannya. Keputusan pemerintah untuk tetap menyelenggarakan pemilihan umum kepala daerah pada tahun 2020 ini membawa konsekuensi logis bahwa legitimasi serta keabsahan hasil pemilihan umum kepala daerah ini mutlak diperlukan. Legitimasi ini akan membawa jalannya roda pemerintahan menjadi lebih mudah dijalankan karena pemerintah tidak hanya terdiri dari komponen eksekutif dan yudikatif, namun juga didukung dengan keputusan masyarakat sebagai pelaksana sebuah regulasi yang dibuat nantinya. Menurut Miriam Budiarjo, legitimasi akan terkait dengan kedudukan seseorang ataupun kelompok pimpanan yang diterima dengan baik oleh masyarakat sehingga masyarakat akan turut serta dengan segala keputusan yang dibuat oleh penguasa karena adanya asas kewajaran dari keputusan penguasa tersebut. ${ }^{39}$

Secara teknis, legitimasi kemudian amat erat kaitannya dengan keabsahan hasil pemilihan umum kepala daerah tahun 2020. Keabsahan dimaksud adalah tata laksana prosedural yang digunakan dalam proses pemungutan suara hingga sampai kepada tahap rekapitulasi suara yang kemudian dari hasil rekapitulasi suara tersebut akan

37 Praveen Menon. (2020). New Zealand's Ardern Postpones Election as Coronavirus Flares Up. https://www.reuters.com/article/us-newzealand-election-ardern-idUSKCN25C0UW. Diakses pada 3 Februari 2021.

38 Vasil Vaschanka. (2020). Political Manoeuvres and Legal Conundrums Amid the Covid-19 Pandemic: The 2020 Presidential Election in Poland. International IDEA: Stockholm, h. 7.

${ }^{39}$ Miriam Budiarjo. (2012). Dasar-Dasar Ilmu Politik. Gramedia: Jakarta. h. 44. 
ditentukan siapakah pasangan calon pemenang hasil pemilihan umum. Terkait dengan keabsahan, maka hal ini akan amat terkait dengan hukum secara tekstual yang berdasar kepada peraturan perundang-undangan yang berlaku mengenai pemilihan umum. ${ }^{40}$ Secara teknis, hasil pemilihan umum dapat dikatakan sah ketika telah ditetapkan oleh Komisi Pemilihan Umum serta tidak adanya gugatan sengketa hasil pemilihan umum pada Mahkamah Konstitusi.

Berbeda dengan keabsahan hasil pemilihan umum, legitimasi kemudian tidak dapat diukur secara rinci menggunakan angka. Secara awam, angka partisipasi pada proses pemilihan umum serta angka hasil pemilihan umum memang dapat dijadikan acuan awal, namun tidak berarti proses pemilihan umum tersebut lantas mendapatkan kepercayaan secara utuh dari masyarakat. Legitimasi kemudian dapat menjadi salah satu fungsi kontrol dari masyarakat terhadap pemerintah, utamanya dalam hal ini adalah eksekutif di tingkat daerah sebagai pemenang proses pemilihan umum serentak tahun 2020.41 Menurut Eli Berman, legitimasi kemudian dapat diukur dengan beberapa indikator, yakni:42

1. Iklim demokrasi di daerah pelaksanaan pemilihan umum

2. Penegakan hukum pemilihan umum oleh aparat penegak hukum maupun instrumen hukum terkait yang telah dibentuk

3. Keterlibatan anggota parlemen serta eksekutif dalam proses pengambilan kebijakan yang berpihak kepada para pemilih; dan

4. Adanya keinginan masyarakat untuk melaporkan tindakan-tindakan koruptif selama proses pemilihan umum berlangsung dari awal hingga akhir rangkaian.

Menjadi permasalahan pada gelaran pemilihan kepala daerah serentak tahun 2020 ini adalah tantangan Pandemi Covid-19 yang masih mengancam keselamatan masyarakat. Tingginya kemungkinan seseorang untuk terpapar virus ini pula akan mengubah sebara demografi peserta pemilihan umum, dalam hal ini adalah pemegang hak suara. Pemegang hak suara yang memiliki resiko lebih tinggi untuk terpapar virus Covid-19 akan memiliki kecenderungan untuk tidak mengikuti gelaran kontestasi pemilihan umum kepala daerah serentak. ${ }^{43}$ Hal ini kemudian terlihat pada gelaran pemilihan kepala daerah serentak tahun 2020 yang secara nasional hanya memiliki tingkat partisipasi sekitar 69 hingga $70 \% .{ }^{44}$

40 Widodo Ekatjahjana. (2009). "Menggagas Peradilan Partai Politik dan Pemilu dalam Sistem Ketatanegaraan Indonesia". Jurnal Konstitusi, Volume 2 Nomor 1. Juni 2009. h. 78.

${ }^{41}$ Ansori. (2017). "Legalitas Hukum Komisi Pemilihan Umum Daerah dalam Menyelenggarakam Pilkada". Jurnal Konstitusi, Volume 14 Nomor 3. September 2017. h. 567.

${ }^{42}$ Eli Berman, Michael Callen, Clark Gibson, dan James Long. (2014). Election Fairness and Government Legitimacy in Afghanistan. National Bureau of Economic Research: Massachusetts. h. 3.

${ }^{43}$ Andrew F. Johnson, Wendy Pollock, dan Beth Rauhaus. (2020). “Mass Casualty Event Scenarios and Political Shifts: 2020 Election Outcomes and the U.S. Covid-19 Pandemic". Administrative Theory and Praxis Journal. Volume 42 Nomor 2. h. 5.

44 Sania Mashabi. (2020). KPU: Partisipasi Pemilih di Pilkada 2020 Capai 76.09 Persen. https://nasional.kompas.com/read/2020/12/31/18260221/kpu-partisipasi-pemilih-di-pilkada2020-capai-7609-persen?page $=$ all. Diakses pada 21 Januari 2021 
Turunnya jumlah partisipasi ini menandakan bahwa ada segolongan masyarakat yang kemudian tidak melakukan proses pemungutan suara yang diakibatkan karena kondisi darurat Pandemi Covid-19. Apabila ditelaah lebih detil melalui angka partisipasi, maka legitimasi pemilihan umum kepala daerah serentak tahun 2020 kurang lebih hanya sebesar $60 \%$. Hal ini tentu saja akan memberikan dampak yang tidak mudah bagi jalannya roda pemerintahan bagi para pemenang kontestasi pemilihan umum tersebut. Dampak utama yang akan timbul adalah pro dan kontra dalam proses pengambilan kebijakan pada masing-masing daerah baik di tingkat Kabupaten atau Kota dan juga tingkat Provinsi.

Legitimasi kemudian akan pula berpengaruh pada proses penentuan dan pengambilan kebijakan di tingkat daerah. Kebutuhan untuk membuat kebijakan yang partisipatif dan mendukung segala kegiatan masyarakat mutlak diperlukan untuk tercapai suatu pemerintahan daerah yang responsif. Legitmasi hasil pemilihan umum dan jalannya roda pemerintahan akan membentuk suatu hubungan kausalitas dimana legitimasi merupakan awal dari sebuah kepercayaan masyarakat untuk menjalankan pemerintahan berdasarkan asas good governance. ${ }^{45}$ Menurut Gilley, faktor penentu dari legitimasi hasil pemilihan umum adalah adanya kepercayaan masyarakat. ${ }^{46}$ Rendahnya tingkat kepercayaan masyarakat melalui lembaga pemilihan umum akan berakibat kepada rendahnya tingkat kepatuhan masyarakat terhadap segala kebijakan yang dibuat oleh pemerintahan definitif. Resiko tersebut harus dijalankan oleh pemerintah definitif sebagai sebuah konsekuensi dasar penyelenggaraan pemilihan kepala daerah serentak 2020 di tengah kondisi pandemi yang berakibat pada berkurangnya legitimasi masyarakat mengingat resiko terhadap ancaman terpapar pandemi Covid-19 yang amat tinggi.

\section{PENUTUP}

Beberapa penjabaran yang telah dipaparkan pada bagian awal hingga sampai kepada bagian kesimpulan kemudian akan dikerucutkan ke dalam beberapa butir kesimpulan, yakni antara lain:

1. Bahwa pemahaman mengenai legitimasi melalui penjabaran makna kata legitimasi baik secara luas mapupun sempit mutlak diperlukan. Secara umum legitimasi dapat diartikan sebagai terjalinnya sebuah hubungan kontrak sosial antara pemilih dengan pasangan calon peserta pemilihan umum yang mana hubungan kontraktual sosial tersebut akan memudahkan siapapun pemenang kontestasi pemilihan umum untuk menjalankan segala kebijakan dalam pemerintahannya.

2. Pemilihan umum pada kondisi darurat pada dasarnya tetap dapat dilaksanakan dengan tetap mengutamakan kondisi masyarakat sebagai peserta pemilik hak pilih sebagai persyaratan utama. Terkait dengan Pandemi Covid-19 yang telah ditetapkan

\footnotetext{
45 Juanda Nawawi. (2012). "Membangun Kepercayaan dalam Mewujudkan Good Governance". Jurnal Ilmiah Ilmu Pemerintahan. Volume 1 Nomor 3. Juni 2012. h. 21.

46 Gilley Bruce. (2006). "The Determinants of State Legitimacy: Results for 72 Countries". International Political Science Review Journal. Volume 27 Nomor 1. h. 50.
} 
oleh Pemerintah Republik Indonesia, pemerintah Republik Indonesia mengambil pilihan untuk tetap menjalankan proses kontestasi demokrasi ini dengan melakukan pergeseran waktu pelaksanaan yang telah diatur melalui suatu peraturan perundangundangan. Pelaksanaan pemilihan umum dalam kondisi Pandemi Covid-19 sendiri merupakan pilihan logis yang harus dilaksanakan. Beberapa negara di dunia juga menyelenggarakan pemilihan umum, antara lain Korea Selatan, Polandia, dan Selandia Baru memilih untuk tetap melaksanakan pemilihan umum dengan merubah kebiasaan-kebiasaan dalam proses pemungutan suara. Protokol kesehatan yang ketat menjadi hal yang wajib dijalankan dalam setiap tahapan proses pemilihan umum.

3. Pemilihan umum kepala daerah serentak tahun 2020 sendiri pada akhirnya telah terlaksana pada 9 Desember 2020. Hal yang perlu diperhatikan dalam proses kontestasi demokrasi ini adalah tingkat partisipasi masyarakat yang kemudian mengalami penurunan dibandingkan dengan pemilihan kepala daerah pada tahun 2015. Tingkat partisipasi pada dasarnya bukanlah alat utama untuk mengukur seberapa jauh legitimasi hasil pemilihan umum, namun tingkat partisipasi ini dapat menjadi indikator awal seberapa jauh legitimasi masyarakat terhadap pemenang pemilihan umum yang kemudian akan memimpin jalannya roda pemerintahan. Semakin tingginya legitimasi masyarakat terhadap pelaksanaan pemilihan umum, akan memudahkan pemerintah untuk membuat kebijkan yang sesuai dengan kebutuhan masyarakat. Masyarakat akan senantiasa memberikan dukungan penuh terhadap segala regulasi pemerintah.

Pemilihan umum dalam keadaan darurat adalah sebuah keniscayaan. Demokrasi serta hak-hak konstitusional masyarakat harus tetap berjalan dalam kondisi apapun. Meskipun pelaksanaan pemilihan umum pada dasarnya dapat dilakukan penundaan ketika mengalami keadaan darurat sesuai dengan amanah Pasal Pasal 120 UndangUndang Nomor 1 Tahun 2015 tentang Penetapan Peraturan Pemerintah Pengganti Undang-Undang Nomor 1 Tahun 2014 tentang Pemilhan Gubernur, Bupati, dan Walikota menjadi Undang-Undang. Faktanya hal ini perlu diatur secara lebih lanjut melalui peraturan pelaksana, agar negara selalu siap untuk menjalankan roda demokrasi dalam kondisi apapun serta tidak merugikan hak-hak konstitusional masyarakat.

\section{DAFTAR PUSTAKA}

\section{Buku}

Alfian, Alfan. (2009). Menjadi Pemimpin Politik: Perbincangan Kepemimpinan dan Kekuasaan. Jakarta: Gramedia Pustaka Utama.

Below, Regina., Wirts, Angelika., \& Guha, Debarati. (2009). Disaster Category Classification and Peril Terminology for Operational Purposes. Munich: Center for Research on Epidemology of Disaster.

Berman, Eli., Callen, Michael., Gibson, Clark., \& Long, James. (2014). Election Fairness and Government Legitimacy in Afghanistan. Massachusetts: National Bureau of Economic Research.

Budiarjo, Miriam. (2012). Dasar-Dasar Ilmu Politik. Jakarta: Gramedia. 
Hermawan, Eman. (2005). Politik Memberla yang benar. Yogyakarta: DKN Garda Bangsa.

Marijan, Kacung. (2010). Sistem Politik Indonesia: Konsolidasi Demokrasi Pasca Orde Baru. Jakarta: Penerbit Kencana Media.

Moore Martin., \& Tambini, Damian. (2018). Digital Dominance, The Power Of: Google, Amazon, Facebook, and Apple. Oxford: Oxford University Press.

Republic of Korea National Election Commission. (2020). Election Management in Response to Covid-19. South Korea: Republic Of Korea National Election Commission.

Smith, Alsatair. (2004). Election Timing. Cambridge: Cambridge University Press.

Surbakti, Ramlan. (2009). Memahami Ilmu Politik. Jakarta: Grasindo.

Vaschanka, Vasil. (2020). Political Manoeuvres and Legal Conundrums Amid the Covid-19 Pandemic: The 2020 Presidential Election in Poland. Stockholm: International IDEA,

\section{Jurnal}

Ansori. (2017). Legalitas Hukum Komisi Pemilihan Umum Daerah dalam Menyelenggarakam Pilkada. Jurnal Konstitusi. 14(3), 567.

Arifulloh, Achmad. (2015). Pelaksanaan Pilkada Serentak yang Demokratis, Damai, dan Bermartabat. Jurnal Pembaharuan Hukum. 2(2), 301.

Bruce, Gilley. (2006). The Determinants of State Legitimacy: Results for 72 Countries. International Political Science Review Journal. 27(1), 50.

Casmi Arrsa, Ria. (2014). Pemilu Serentak dan Masa Depan Konsolidasi Demokrasi. Jurnal Konstitusi. 11(3), 522-523.

Chandra, Andi., Darmawan, Erik., \& Yesi. (2018). Upaya Komisi Pemilihan Umum Provinsi Sumatera Selatan Dalam Meningkatkan Partisipasi Pemilih Pilkada Serentak 2018 dan Pemilu Serentak 2019. Jurnal Studi Sosial dan Politik. 2(1), 14.

Choirul Rizki, Singgih ., \& Adam Hilman, Singgih. (2020). Menakar Perbedaan Opini Dalam Agenda Pelaksanaan Kontestasi Pilkada Serentak di Tengah Covid-19. Jurnal Muqqadimah: Jurnal Ilmu Sosial, Politik, dan Humaniora. 4(2), 145.

Ekatjahjana, Widodo. (2009). Menggagas Peradilan Partai Politik dan Pemilu dalam Sistem Ketatanegaraan Indonesia. Jurnal Konstitusi. 2(1), 78.

F. Johnson, Andrew., Pollock, Wendy., \& Rauhaus, Beth. (2020). Mass Casualty Event Scenarios and Political Shifts: 2020 Election Outcomes and the U.S. Covid-19 Pandemic. Administrative Theory and Praxis Journal. 42(2), 5.

Jamaludin, Teten. (2019). Pilkada Langsung: Kisah Sukses dan Problematika. Jurnal Politik Walisongo. 1(1), 32.

James, Toby., \& Alihodzic, Sead. (2020). When Is It Democratic To Postpone an Election? Elections During Natural Disasters, Covid-19, and Emergency Situation. Election Law Journal. 19(3), 347.

Lestari Ginting, Yoremia. (2016). Mekanisme Tata Kelola dan Pengungkapan Tanggung Jawab Sosial Perusahaan. Kinerja. Jurnal Ekonomi dan Manajemen. 13(1), 75.

Nawawi, Juanda. (2012). Membangun Kepercayaan dalam Mewujudkan Good Governance. Jurnal Ilmiah Ilmu Pemerintahan. 1(3), 21.

Ristyawati, Aprista. (2020). Efektivitas Pelaksanaan Pilkada Serentak 2020 di Masa Pandemi Darurat Covid-19 di Indonesia. Jurnal Crepido. 2(2), 4. 
Sri Hardjanto, Untung. (2019). Legitimasi Pemilihan Umum di Indonesia Tahun 2019. Administrative Law and Governance Journal. 2(1), 110.

Sutrisno, Cucu. (2017). Partisipasi Warga Negara dalam Pilkada. Jurnal Pancasila dan Kewarganegaraan. 2 (2), 36.

\section{Website}

Antonio Spinelli. 2020. Managing Election Under the Covid-19 Pandemic: The Republic of Korea's Crucial Test. International IDEA Technical Paper. idea.int/sites/default/files/publications/managing-elections-during-pandemicrepublic-korea-crucial-test.pdf.

Charlotte Cousins. 2020. Holding Elections During the Covid-19 Pandemic. https://data.oireachtas.ie/ie/oireachtas/libraryResearch/2020/2020-12-16_l-rs-note-holdingelections-during-the-covid-19-pandemic_en.pdf. 3 Februari 2021.

Elina Budiarti. 2015. Di Balik Partisipasi Pilkada 2015 yang Menurun. https://www.bbc.com/indonesia/berita_indonesia/2015/12/151210_indonesia_pilkada. 29 Januari 2021.

Abdul Rochim. 2020. Penundaan Pilkada, Rem Darurat Cegah Klaster Baru Covid-19. https://nasional.sindonews.com/read/162040/12/penundaan-pilkada-rem-darurat-cegahkluster-baru-covid-19-1599869369? showpage=all. 2 Februari 2021.

Hakam. 2020. Dilema Pelaksanaan Pilkada Serentak di Tengah Ancaman Pandemi. https://ugm.ac.id/id/berita/20283-dilema-pelaksanaan-pilkada-serentak-di-tengah-ancamanpandemi. 21 Januari 2020.

Humas Mahkamah Konstitusi. 2020. Sekretaris Jendral Mahkamah Konstitusi: Keselamatan Warga Hukum Tertinggi. https://www. mkri.id/index.php?page=web.Berita\&id=16326. 21 Januari 2021.

Kevin P. Clements. 2014. What is Legitimacy and Why Does It Matter for Peace? https://rcservices-assets.s3.eu-west-1.amazonaws.com/s3fs-public/Accord25_WhatIsLegitimacy_0.pdf. 30 Januari 2021.

Kimmo Gronlund dan Maija Setala. 2004. Low Electoral Turnout an Indication of Legitimacy Defisit? https://ecpr.eu/Filestore/paperproposal/d83ddd59-0a00-4535-a11755a859e6a630.pdf. 30 Januari 2021.

Pippa Noris, Richard Frank, dan Ferran Martinez. 2014. Measuring Electoral Integrity Around the World: A New Dataset. https://core.ac.uk/download/pdf/71804807.pdf. 3 Februari 2021.

Praveen Menon. 2020. New Zealand's Ardern Postpones Election as Coronavirus Flares Up. https://www.reuters.com/article/us-newzealand-election-ardern-idUSKCN25COUW. 3 Februari 2021.

Sania Mashabi. 2020. KPU: Partisipasi Pemilih di Pilkada 2020 Capai 76.09 Persen. https://nasional.kompas.com/read/2020/12/31/18260221/kpu-partisipasi-pemilih-di-pilkada2020-capai-7609-persen?page=all. 21 Januari 2021.

Sania Mashabi. 2020. KPU: Partisipasi Pemilih di Pilkada 2020 Capai 76.09 Persen. https://nasional.kompas.com/read/2020/12/31/18260221/kpu-partisipasi-pemilih-di-pilkada2020-capai-7609-persen?page $=$ all. 21 Januari 2021 
Tsarina Maharani. 2020. DPR: Beberapa Negara ada yang Sukses Laksanakan Pemilu di Tengah Pandemi. https://nasional.kompas.com/read/2020/09/22/12573411/dpr-beberapanegara-ada-yang-sukses-laksanakan-pemilu-di-tengah-pandemi?page=all. 21 Januari 2021.

Yoga Pongluturan, Martha Eliza Sellyn, Adryan Frediyanto. 2020. Kacamata Driyarkara : Pelaksanaan Pilakada 2020 di Titik Nadir. https://usd.ac.id/mahasiswa/bem/f1l3/Kajian\%20Pilkada\%20Pandemi\%20SPKS.pdf. 3 Februari 2021.

\section{Peraturan Perundang-Undangan}

Undang Undang Nomor 6 Tahun 2020 tentang Penetapan Peraturan Pemerintah Pengganti Undang-Undang Nomor 2 Tahun 2020 tentang Perubahan Ketiga atas Undang-Undang Nomor 1 Tahun 2015 tentang Penetapan Peraturan Pemerintah Pengganti Undang-Undang Nomor 1 Tahun 2014 tentang Pemilihan Gubernur, Bupati, dan Walikota Menjadi Undang-Undang menjadi Undang-Undang. Lembaran Negara Republik Indonesia Tahun 2020 Nomor 193. Jakarta.

Undang-Undang Nomor 1 Tahun 2015 tentang Penetapan Peraturan Pemerintah Pengganti Undang-Undang Nomor 1 Tahun 2014 tentang Pemilihan Gubernur, Bupati, dan Walikota menjadi Undang-Undang. 2 Oktober 2014. Lembaran Negara Republik Indonesia Tahun 2014 Nomor 245. Jakarta.

Undang-Undang Nomor 7 Tahun 2017 tentang Pemilihan Umum. 15 Agustus 2017. Lembaran Negara Republik Indonesia Tahun 2017 Nomor 573. Jakarta.

International Covenant of Civil and Political Rights sebagaimana diratifikasi melalui UndangUndang Nomor 12 Tahun 2005 tentang Pengesahan International Covenant of Civil and Political Rights. 28 Oktober 2005. Lembaran Negara Republik Indonesia Tahun 2005 Nomor 119. Jakarta.

Putusan Mahkamah Konstitusi Nomor 14/PUU-XI/2013 